\title{
A “Queer” Manifesto of Interventions for Libraries to "Come Out” of the Closet! A Study of “Queer” Youth Experiences during the Coming Out Process
}

\author{
Bharat Mehra (Assistant Professor, School of Information Sciences, University of \\ Tennessee) email: bmehra@utk.edu \\ and \\ Donna Braquet (Assistant Professor and Life Sciences Librarian, Hodges Library, \\ University of Tennessee).
}

\begin{abstract}
Based on qualitative analysis of data gathered during in-depth narrative interviews and informal discussions about "queer” youth experiences with twenty-one "queer" individuals, this paper presents a "queer" manifesto of library interventions in support of "queer" youth during various phases of the coming out process. Important characteristics of coming out are discussed, especially as a life-long process for "queer" individuals to acknowledge their sexuality and share that awareness with others. Significant concerns and challenges faced by “queer” youth during different phases in their coming out experiences provide a context for the identification of library interventions that reflect (and require) extending traditional library functions of information provision as well as fulfilling non-traditional expectations that include proactive social justice efforts for libraries to come out of the closet in support of "queer" youth.
\end{abstract}

Keywords “queer" youth, library interventions, coming out process, qualitative research

\section{Introduction}

A foremost concern of library educators, practitioners, and other information professionals working with youth is the provision of appropriate information since awareness, application, and developing access to meaningful information is the main service that youth need (Farmer, 2003; Danesi, 2003; Winston \& Paone, 2001). Yet wide gaps exist between the information concerns and choices of contemporary youth and the specific information services provided at libraries and information centers for this underserved population (Shenton \& Dixon, 2002). Youth activists attribute these information gaps to several factors; significant among them are lack of systematic study about youth services and library use by youth that go beyond anecdotal reports (Spielberger, Horton, Michels, \& Halpren, 2004); low prioritizing of library youth services owing to challenges of funding restraints, changing personnel structures, ambivalence towards changing technologies, and changing youth expectations (Willett, 1995); lack of in-depth and detailed examination of youth concerns while designing library services (Dresang, Gross, \& Holt, 2003); frequently ignoring the perspectives and responses of youth (Bishop \& Bauer, 2002); biased justification for information provision 
in libraries based on mere quantitative measures that are recorded for statistical validation and evaluation (Machado, Lenz, \& Wallace, 2000); and modern librarians' desire to jump on the band-wagon of focusing solely on technology use by youth without relating applications and services to offline realities and real-life concerns and challenges (Walter, 1997). A recent study sponsored by The Pew Internet \& American Life Project indicated that a majority of young people ages 12 to 17 years from middle and high schools did not like using the library for the following reasons: 1) difficulty in getting printouts of information; 2) waiting in line to check out books; 3) lack of useful resources; 4) failure of librarians to be helpful; and 5) services and resources not related to topics of personal interest (Levin \& Arafeh, 2004).

Such general concerns about inadequate library and information services and poor usage perceptions that are applicable to youth have a deeper, more poignant significance in the light of current studies that identify greater risks and higher rates of suicide among “queer"1 young Americans today (LaBarbera, 1996; Dorais \& Lajeunesse, 2003). For example, recent research on "queer" youth reveals the following noteworthy findings: 1) sexual minority youth are among the most likely to report suicidality (suicidal thoughts, plans, and attempts) (Russell, 2003); 2) what leads “queer” youth to a suicidal path is not their sexuality but the stigma and discrimination they encounter in a heterosexual world (Perrin et al., 2004). These findings are important in the context of interviews with thousands of young “queer” individuals who identify a need for adequate resources, people, and places that provide accurate and supportive information in order to make their sexuality-related experiences easier and less painful, both at a personal level and at the level of social acceptance (Joyce, 2003; Connexions, 2002/2003).

Libraries must awaken to the reality of such marginalizing experiences shared by “queer” individuals (Joyce \& Schrader, 1997). This is especially necessary in the context of common public perception that the current climate since President George W. Bush's re-election to the White House for the second consecutive term has resulted in a recognizable growth in the conservative political and religious intolerance for sexual minorities (Utter \& True, 2004): for example, people have identified parallels between the recent anti-gay marriage laws passed by eighteen states and past laws banning interracial marriage (Pascoe, 2004).

Libraries have the opportunity to play a more meaningful role in the lives of “queer” youth (Fikar \& Koslap-Petraco, 1991) through their professional capacity of

\footnotetext{
1 "Queer" is used in this paper to include gay, lesbian, bisexual, transgender, and questioning youth. The authors recognize the word "queer" to be most inclusive to represent sexual minorities since it covers all individuals who do not identify with or are not recognized as part of a heterosexual majority. Following the work of Foucault (1980), this paper follows the contemporary use of the abusive word "queer" by advocate groups as a mark of ownership, empowerment, and appropriation that ironically self-consciously historicizes and marks the repressive character of social discourses surrounding sexuality (Blasius, 2001; Garber, 1995). Quotation marks (“”) are used with the word "queer” in this paper to recognize the history of abuse, ridicule, discrimination, and violence projected against "queer" people and to point to the need to reexamine the past and to turn the situation around via building a more progressive and accepting cultural environment.
} 
supporting and developing activities related to information creation, organization, and dissemination processes (Mehra, 2005). Novel approaches to addressing the needs of "queer" youth will require the provision of adequate information support services (Rankin, 1999). It also means that libraries have to take a more aggressive political stance as supporters of social justice that extends their traditional roles of information providers and containers of world knowledge (Howrey, 2000). This implies that libraries have to advocate the next step forward that applies meaningful knowledge and translates progressive information into concrete actions to develop profound community wisdom. Such community wisdom will allow individuals, groups, and institutions to recognize and rejoice in their diversity, inclusive and accepting of "queer" individuals.

Library support and leadership towards this vision are necessary (McDowell, 2000). Libraries will have to develop strategies to become identified by the community as safe havens for "queer" youth. They will have to channel their efforts and focus their services towards supporting individual empowerment, social acceptance, and proactive engagement with the community to wipe out homophobia, intolerance, prejudice, and discrimination based on perceptions associated with sexual orientation and gender identity. Only then will libraries become recognized as leaders in society, for they will connect action to words and reflect a willingness to grapple with uncomfortable social issues in order to promote progressive change marked by social justice, equality, fairness, and acceptance of all, regardless of any qualifying markers.

Becoming agents of change in society in order to remove ignorance and help develop acceptance towards all forms of diversity, inclusive of "queer” individuals, is not going to be an easy task for libraries. In the recent past, "queer" people have been shunned, ridiculed, and often ignored or considered "invisible" from any discussion surrounding diversity (Argus \& Cox, 1999), including those that have taken place around the library table. The stigma of being "queer" has weighed so heavily on the shoulders and psyches of modern American society as a disgraceful and against nature phenomena that even today “don't-ask-don't-tell” philosophies are ardently indoctrinated and implemented in many national, state, and local level jurisdictions, the military and sports industry being two (Herek, Jobe, \& Carney, 1996). What has been most difficult and painful for "queer" individuals has been the witnessing and experiencing of such reactions, not just from the right-wing religious fundamentalists but even from lay people, their families, and their next-door neighbors, who have acted as if they did not exist, turning a blind eye to their struggles in being closeted with a polite smile on their faces and ignoring their commitment to endearing relationships with their same-sex partners (Beaty, 1999), hoping that by some divine intervention they would be wiped off the face of the Earth!

Such a dissolution has, of course, not occurred; and "queer" people of all racialethnic backgrounds, ages and genders, incomes and geographic residencies have continued to emerge across social spaces, community places, local centers, and isolated margins in our society (Laumann, Ellingson, Mahay, Paik, \& Youm, 2004). At the same time, however, we have witnessed an increase of nationwide tangible and intangible policies of bigotry and discrimination set in motion against "queers" by actions supported 
by legislatures, fundamentalist religious groups, local businesses and multinational corporations, faith-based community organizations, media and newspapers, and specific individuals (Gross \& Woods, 1999). We have also seen how, even during recent years, in the midst of our often proud proclamations of a civilized society, we find "queer" people being beaten and harassed, even tortured and killed as seen in the horrible death of Matthew Shepard in Wyoming during 1998 (Crowley, 2004). Shepard's murder was a wakeup call for "queer" individuals and allies to be silent no more against bigotry, intolerance, and injustice (Swigonski, Mama, \& Ward, 2001). Though subsequent movements in support of "queer" rights are having profound influences upon "queer" youth of today — as seen in their intolerance towards intolerance in recent years (Flint, 2004) - libraries have been slow in their efforts to propel society toward change owing to their complacent mindsets and conservative middle-class roots (Blasius, 2001). Another reason for libraries' failure to take progressive action in support of "queer" individuals has been a lack of direction in making consolidated and systematic change that may affect and impact “queer” individuals in self-affirming and meaningful ways (Kirsch, 2001).

In the context of the slow emergence of "queer" youth information support services in libraries owing to a modern-day cloud of pervasive homophobic "moral values" shutting out any supportive gesture towards people of alternative sexualities (Blumenfeld, 1992), this paper provides concrete mechanisms for libraries to participate in communitywide interventions in support of "queer" youth. Based on youth experiences of "queer" individuals, this paper outlines specific concerns and challenges faced by "queer" youth and corresponding library and information interventions that need to be taken during various phases of the coming out process. The belief that there is a need for library interventions is based on the assumption that "queer" individuals form a marginalized group that have historically been left out in terms of library provisions of adequate information services and social support (Cianciotto \& Cahill, 2003). By documenting the concerns and challenges that "queer" individuals have faced during their youth in the coming out process, the study takes a critical approach to give voice to underrepresented and disenfranchised experiences. It also fills gaps in the limited and skimpy research on library use by "queer" youth during the process of coming out. Identifying progressive and more responsive efforts needed from library and information professionals addresses the needs of those young people who may be struggling with a lack of information about sexuality-related issues, not knowing where to find social and cultural support to address their concerns related to sexuality, sexual orientation, and/or gender identity.

\section{A Review of Coming Out Literature}

Recent research on the homosexual coming out experience considers the lifelong process as "simply about being true to yourself" in "identifying one's self as gay, lesbian, bisexual, or transgender" and disclosing this to other people (Human Rights Campaign, 2004). A focus of this paper is on library action, and the proposed manifesto for libraries calls for improvements in the design of their information support systems, services, collections, and institutional policies to provide greater support to "queer" youth in their 
coming out process. The hope of the authors is that such efforts will also make a significant difference in lowering suicide rates among "queer” youth.

Several researchers and theorists consider the coming out process for "queer" youth as a significant development in their identity formation (Anderson, 1993; Stenback \& Schrader, 1999). Coming out of the proverbial closet of secrecy is regarded as a continuum that goes beyond "in and out" choices of either one or the other. Self-andsocial identification as homosexual and strategies to address the social dynamics and socialization issues that emerge as a result of the disclosure are chief concerns that "queer" individuals face during coming out (Westheimer, 1995). Though the costs of "queer" disclosure include potential rejection, discrimination, alienation, or violence (Fassinger, 1991), benefits are believed to outweigh costs and include the development of a positive "queer” identity, psychological adjustment, and enhanced self-esteem and selfacceptance (Troiden, 1979).

Phases in the coming out process broadly include the following (Cass, 1979; George \& Behrendt, 1989): self-recognition as "queer"; disclosure to other "queer" people (who may initially be strangers in a broader social network) that helps to build a "queer" support system with "like" people; disclosure to members from the inner social network that includes family, relatives, friends, co-workers, and employers; positive selfidentification; and integration and acceptance. Cass (1984) further explains the identification and socialization journey in coming out from a heterosexual to a homosexual to include identity confusion, identity comparison, identity tolerance, identity acceptance, identity pride, and identity synthesis. Researchers have argued over what the authors consider minor points of contention such as whether disclosure to the “other” implies other heterosexual or “queer” people (Coleman, 1982) and whether selfidentification is a stage within or distinct from coming out (Lee, 1977; Hooker, 1965). Both controversies seem insignificant, for in their dictatorial need for developing overarching generalizations, some researchers do not recognize the complexity and multiplicity in coming out experiences, nor do they acknowledge their linguistic and symbolic descriptions to be mere constructions of communication and definition that the reality of the multiplicity of experiences transcends.

Health professionals compare the coming out process to the stages in grieving, i.e., denial, anger, bargaining, depression, and acceptance (Kubler-Ross, 1993). Temes (1980) identifies the stages of grief in terms of numbness, disorganization, and reorganization; and varied degrees of these are expressed during different “queer” youths' coming out processes based on individual experiences, degree of internalization of socio-cultural expectations, and perceived environment of hostility and acceptance. Coleman (1982) says that the stigma in American society attached to homosexuality causes people with same-sex attractions "to develop negative conceptions of themselves" (p. 149). Consequently, providing truthful and sympathetic information during such painful times becomes a necessity that can make a difference between life and death for "queer" youth. Libraries can play an important role in this effort by recognizing that coming out is considered a process, “a journey, not a destination,” and by taking positive and concrete steps to address three significant issues related to coming out, namely (AVERT, 2003), 1) 
coming out is a necessary experience for "queer” youth, yet confusion about identity during the process can affect an individual's self-esteem, school work, and social relationships (both negatively and positively); hence the need for a supportive environment to address issues of coming out for "queer" youth is extremely important; 2) while deciding who to tell about their sexuality, young "queer" people have well-founded fears of negative reactions and rejection or causing distress to the person they are telling; 3) a non-judgmental and supportive environment, guarantees of safety, availability of secure and confidential contacts to reduce anxiety and overcome isolation, presence of role models, and positive treatment to feel confident about their future are some positive directions of support for "queer” individuals during coming out.

\section{Research Methods}

The paper uses qualitative research methods involving in-depth narrative interviews and informal discussions about youth experiences of coming out. The participants were twenty-one "queer" individuals self-identified as gay, lesbian, bisexual, transgender, or questioning who reside in a representative southern city in the United States. Research findings identify appropriate library interventions suggested by the participants. These interventions would have ideally made their coming out process less painful at different times during their youth. Based on self-identification, there were two lesbians, twelve gay men, six bisexuals (four women and two men), and one heterosexual transgender (female-to-male) individual who participated in this study. The authors recognize much variation in experiences of the participants based upon their identification as gay, lesbian, bisexual, or transgender. It is important not to minimize these differences. Owing to a lack of significant numbers in this study to represent the different groups, future research will correlate these sexual identity-related labels with patterns in participant responses and the proposed interventions they suggest for different phases of the coming out process. Findings in this study show an underlying shared sense of being "marginalized" as sexual minorities that was reflected in the youth experiences and that established a common platform encompassing the various demarcating labels of difference (Gough \& Greenblatt, 1990). This paper recognizes both the differences and the shared sense of "marginalization" in the individual "queer" youth experiences and calls for the provision of information support services in libraries during various coming out phases that acknowledges variations beyond broad generalizations.

In order to maintain anonymity of the participants, the methodological execution of narrative interviews and informal discussions took place in private meeting rooms at the local academic library. Meetings were facilitated during formal, structured interactions with participants who were initially elicited to participate via personal contacts and through such local "queer"-related agencies and organizations on the university campus and in the community as The Lambda Student Union and local electronic mailing lists. Flyers to elicit participation were posted at popular places such as libraries, the student union, local cafes, and “queer" events organized by students. Methods of snowballing sampling proved significant in locating participants for later interviews where initial interviewees recommended other "queers" from their social networks to participate in this 
study. Participants signed a consent form indicating their voluntary participation in the research, and each participant was given a \$20 gift certificate as a token of appreciation for his/her efforts.

Narrative interviews with participants lasted from 1.0-2.5 hours each during which participants were asked questions on coming out experiences, concerns and challenges faced, detailed information-seeking behaviors during different times, the kinds of library and information support services participants encountered during the process, and how those resources and services could be improved. Appendix 1 provides a list of some open-ended questions relevant to this research that were asked during the narrative interview sessions. A post interview questionnaire provided demographic characteristics and contextual instrumentals about the case participants.

Based on grounded theory (Glaser \& Strauss, 1967), extensive notes taken during narrative interviews and interview transcriptions were analyzed to generate themes and patterns that helped produce socially relevant understanding of occurring social phenomena (Schwandt, 1994). The process of coding interview data in this research involved socially grounded elements: seeking multiple perspectives as a part of the research inquiry; adopting triangulation strategies that verified specific information from multiple sources; following systematic and rigorous procedures for understanding social processes and phenomena that case participants spoke about; and employing techniques of induction, deduction, and verification to develop theory based on constant comparative analysis (Strauss \& Corbin, 1994). Coding practices encompassed open coding (which accounted for named activities, processes, events, moments of awareness that emerged from the interview data); axial coding (relating categories and subcategories to each other); and selective coding (helped integrate concepts with both the interview questions and the broader coming out perspectives of case participants).

Narrative interviews provided an apt hermeneutic method in this research since they were applied without any preconceived theoretical framework beyond trying to broadly understand the concerns of the participants during their coming out process and to explore possible library interventions that were or could have been used in the process. During the narrative interviews, participants' willingness to tell little stories about their coming out experiences provided a rich source for developing scenarios. Scenarios were pieces of personal narratives that were threaded together and used as a mode of data presentation and analysis in order to reflect participants' perspectives as well as to identify library interventions (see scenarios later in the paper).

Recent research broadly addresses the coming out process of "queer" adults and youth in terms of its general stages and characteristics (Kaufman \& Rafael, 1996). What is missing in such studies is a detailed mapping of the information concerns during each phase of coming out and the social and library interventions that can support "queer" individuals during the process. Based on youth narratives of coming out experiences, this study fills in the gaps in past research and provides a more detailed understanding of information-related concerns of "queer" youth in terms of its determinants, characteristics, nature of information needs, and application towards initiatives that 
libraries and information professionals can support during the coming out process. The study shows that information-related concerns of "queer" individuals during youth are much more complex and incorporate more dimensions than traditionally researched. Mapping the concerns and challenges of "queer" individuals in their coming out process will provide a better understanding of their information needs relative to the provision of library and information support and services. A limitation of this study is that only some participants identified themselves as youth (23 years or below), while others shared their youth experiences about coming out. In this research, this limitation was faced owing to difficulties in obtaining access to younger individuals and cumbersome and timeconsuming bureaucratic procedures for appropriate permissions. Future research will address this limitation and will involve more young people.

\section{Findings}

In the past, scholars have conducted research regarding youth information experiences in different areas that include human information behavior from information sciences, implementation and use studies of information technology in school settings within school library media contexts, information literacy instruction and learning issues, and aspects from instructional design and design of technology for instruction (Chelton \& Cool, 2004). Various theories and models have been proposed to gain understanding of youth information needs in different contexts such as career decision making (Julien, 1999), information searching in business education (Atkinson \& Figueroa, 1997), library book use (Beheshti, 1989), use of online catalogs (Borgman, Hirsh, Walter, \& Gallagher, 1995), Internet web-searching instruction (Kafai \& Bates, 1997), use of web-search engines (Bilal, 2002), utilization of heroin information (Todd, 1999), and many others. One subject that is missing in such work is "queer" youth information experiences during coming out processes. This study provides an approach to address this gap via a proposed model that directly connects information concerns identified by "queer" individuals during their youth experiences to types of information support services that libraries can provide to support them during the coming out process.

\section{Concerns and Challenges in "Queer" Youth Experiences}

Based on participant feedback about their coming out experiences during youth, Table 1 summarizes significant concerns and challenges experienced by participants related to the provision (or lack of provision) of information support services that affected their individual, social, cultural, and/or community marginalization. 


\begin{tabular}{|c|c|c|}
\hline $\begin{array}{l}\text { Sr. } \\
\text { No. }\end{array}$ & $\begin{array}{l}\text { Phases in the } \\
\text { Coming Out } \\
\text { Process }\end{array}$ & Significant Concerns and Challenges \\
\hline 1. & $\begin{array}{l}\text { Self- } \\
\text { recognition as } \\
\text { "queer" }\end{array}$ & $\begin{array}{l}\text { - Fears arising from internalization of heterosexist norms and } \\
\text { expectations } \\
\text { - Perception of lack of social and cultural validation } \\
\text { - Lack of information about "queer” issues in terms of a) } \\
\text { personal and psychological aspects; b) clarification of social } \\
\text { and cultural misperceptions and stereotypes }\end{array}$ \\
\hline 2. & $\begin{array}{l}\text { Disclosure to } \\
\text { other "queer" } \\
\text { people }\end{array}$ & $\begin{array}{l}\text { - Lack of information about where to find "queer" individuals } \\
\text { and social groups } \\
\text { - Recognition of a perceived difference (based on stereotypes) } \\
\text { in norms and behavior among "queer" people } \\
\text { - Lack of awareness of how to behave and interact with other } \\
\text { " "queer" individuals } \\
\text { - Fear of not fitting in with stereotypical "queer" culture }\end{array}$ \\
\hline 3. & $\begin{array}{l}\text { Disclosure to } \\
\text { family/friends }\end{array}$ & $\begin{array}{l}\text { - Fear of disclosure and concealment of "queer" information- } \\
\text { seeking activities } \\
\text { - Fear of rejection from loved ones } \\
\text { - Fear of emotional or physical abuse }\end{array}$ \\
\hline 4. & $\begin{array}{l}\text { Positive self- } \\
\text { identification }\end{array}$ & $\begin{array}{l}\text { - Lack of role models } \\
\text { - Not being able to build a "queer" inner social network } \\
\text { - Misconceptions of "queer" roles and stereotypes }\end{array}$ \\
\hline 5. & $\begin{array}{l}\text { Integration and } \\
\text { acceptance }\end{array}$ & $\begin{array}{l}\text { - How to integrate different elements of personal, social, and } \\
\text { professional life based on openness and social acceptance }\end{array}$ \\
\hline
\end{tabular}

\section{Library Interventions in Support of "Queer" Youth}

Based on participant feedback, table 2 presents a summary of the kinds of activities that public and academic libraries can undertake to "come out" of the closet of heterosexism to become greater proactive supporters of "queer" youth during different coming out phases. 


\begin{tabular}{|c|c|c|}
\hline $\begin{array}{l}\text { Sr. } \\
\text { No. }\end{array}$ & $\begin{array}{l}\text { Phases in the } \\
\text { Coming Out } \\
\text { Process }\end{array}$ & Library Interventions \\
\hline 1. & $\begin{array}{l}\text { Self-recognition } \\
\text { as “queer” }\end{array}$ & $\begin{array}{l}\text { - Train librarians and library staff to provide adequate and } \\
\text { appropriate services in a non-judgmental manner to youth seeking } \\
\text { "queer” information } \\
\text { - Provide discreet mechanisms for reference information sharing } \\
\text { via online and offline means about sexuality-related issues for } \\
\text { questioning or “queer” youth not out of the closet } \\
\text { - Develop aggressive and pro-active advertising of sexuality- } \\
\text { related events and resources } \\
\text { - Share information about local “queer” resources including } \\
\text { counseling and social support services } \\
\text { - Provide access to well-selected materials about coming out and } \\
\text { other related topics that may support “queer” youth } \\
\text { - Recognize that "queer” people (in addition to heterosexual users) } \\
\text { may also use the library (don’t rely solely on patron demand) } \\
\text { - Write a collection development policy and build collections that } \\
\text { include local non-traditional materials on “queer” issues } \\
\text { (brochures from counselors/health professionals helping “queer” } \\
\text { youth in the coming out process) } \\
\text { - Collaborate with schools and/or conduct classes/workshops on } \\
\text { sex education and share sexuality and health information }\end{array}$ \\
\hline 2. & $\begin{array}{l}\text { Disclosure to } \\
\text { other “queer" } \\
\text { people }\end{array}$ & $\begin{array}{l}\text { - Share information about Internet-based (dispersed) and offline } \\
\text { (local) social support groups and services } \\
\text { - Offer library meeting rooms to the "queer" community } \\
\text { - Librarians participate in safe-space programs }\end{array}$ \\
\hline 3. & $\begin{array}{l}\text { Disclosure to } \\
\text { family/friends }\end{array}$ & $\begin{array}{l}\text { - Collect materials for parents and family of “queer” people about } \\
\text { coming out to parents/family } \\
\text { - Offer library meeting rooms to “queer” support groups } \\
\text { - Organize meetings for “queer” parents to share experiences and } \\
\text { support }\end{array}$ \\
\hline 4. & $\begin{array}{l}\text { Positive self- } \\
\text { identification }\end{array}$ & $\begin{array}{l}\text { - Promote dispersed and local “queer” resources (“queer” role } \\
\text { models who have come out, research guides, pathfinders, book } \\
\text { displays/exhibits, film festivals, workshops) } \\
\text { - Co-sponsor programs or panel discussions/forums about “queer” } \\
\text { issues } \\
\text { - Collaborate with “queer” entities to have librarian/the library } \\
\text { listed as a local resource }\end{array}$ \\
\hline 5. & $\begin{array}{l}\text { Integration and } \\
\text { acceptance }\end{array}$ & $\begin{array}{l}\text { - Library acts as a referral to appropriate agencies/departments } \\
\text { - Library and information science profession takes stand for } \\
\text { "queer" community and civil rights and against discrimination } \\
\text { - Librarians work within their community/library/campus to } \\
\text { improve the lives of "queer" people }\end{array}$ \\
\hline
\end{tabular}




\section{Discussion}

Based on qualitative analysis of participant feedback, this section discusses select coming out characteristics, concerns and challenges, and library interventions. Because of the need for brevity, the focus of this discussion is to highlight the key factors associated with coming out as indicated in the above tables.

The stories that participants shared regarding their youth coming out experiences revealed that they perceived coming out in terms of non-sequential and continuous phases instead of clearly demarcated and hierarchical stages. Participants also realized that their coming out experiences were perceived differently by them and by others they encountered; coming out also differed from person to person and was experienced as a combination of phases that could be reordered, reencountered, or might be absent altogether (Scasta, 1998). According to one participant,

My father has remarried and he and his new wife are super religious; they're Catholic, so it has been a “don't-ask-don't-tell” policy with them and I have been forced to go back into the closet with them around. Whereas my mother was completely accepting and has met everybody I have ever dated, loves everybody. But now my mother has also turned religious because of their influence. So after six years of being accepting, she doesn't agree with it, but she loves me, which is all I’ve ever asked for.

Comparing themselves to racial and ethnic minorities who did not have the option of concealing their minority status, "queer" participants in this study self-identified as a "hidden minority" since they had to disclose themselves each time as being "queer" during different occasions (Cain, 1991; Morris, 1997). As another participant observed,

You always have to force yourself to really be out. It's a mental process of going in and coming out that is always going on. When someone asks you, I don't know why it is so uncomfortable to say "this is my girlfriend" or "this is my partner." I guess it is the negative stigma that comes with being gay.

This socially imposed external condition to disclose their sexual identity - in order to refute the heterosexual assumption that others may have made about them-made participants' coming out process (as perceived by them) a life-long process, and each new situation required a weighed decision on whether or not to "come out” (Morris, 1997). Several participants talked about how they realized that this decision-making process would change and evolve over time depending on how they integrated being "queer" into their self-concept and identity (Whitman, Cormier, \& Boyd, 2000).

Thus, while staging models (Cass, 1979; Coleman, 1982; Troiden, 1979) have provided much needed information in the past, libraries may find it more effective to design their services based on findings in this study that point towards a phase model of coming out and discount the use of a linear unidirectional "stage-theory" to explain complexities associated with the entire sexuality of “queer” people (Rivers, 1997). 
Additionally, awareness of coming out phases (instead of stages) is relevant in the design of the information support services that libraries provide in that the provision of different activities and the representation of resources is important although when each individual may need those services may vary. In addition, recognition of multiple and varied coming out experiences calls for incorporating flexibility while developing library and information services in terms of access issues, computer literacy and skills, background and cultural experiences of users, and users' language and vocabulary usage, among other factors.

Participants' youth coming out experiences showed an intersection of multiple factors associated with the individual, people associated with the individual, and the context that shaped their acknowledgement and disclosure of sexuality. These included intersecting variables, including personality and social interaction abilities of the individual, family and social environment, place of growing up, time and cultural backgrounds, socioeconomic status, educational background, age, sex/gender, understanding of sexuality and internalization of sexual-orientation label, living status, and other sociological variables. For example, as a participant reported,

Coming to the realization to myself, I was married, and after my divorce I did not have my first lesbian lover until I was in my early 30s. I lived in rural America and so I had no exposure and although I always knew something, I never acted on it until I moved to New York. So coming to terms with it myself was the hardest over coming to terms with it for anybody else. It took me about a year to accept me. Once I was okay with that, I don't remember having an issue other than approaching my kids.

Such personal narratives documented in this research exposed the coming out process not as "a uniform, ahistorical, stage-driven process" (Herdt, 1992, p. 33) but as a socially and historically constructed process that cannot be used to represent same-sex attraction in all spatial, temporal, and cultural situations. Libraries have to recognize the intertwining and intersecting dimensions of nature and nurture factors that help to shape sexuality as well as how "queer" individuals perceive and internalize the influence of these factors on their sexuality quite differently. Isolating specific factors while providing "queer" related information services in libraries may well prevent reaching out to a greater number of "queer" individuals who may perceive and experience coming out differently from what the library understands. Having flexibility and keeping an open mind while providing information referral on coming out and sexuality are suggestions that will allow librarians to provide meaningful service to a broader "queer" clientele.

Several participants mentioned the importance of both broad and specific information during coming out based on the needs of different individuals. Dank (1971) suggests that one must experience a change in the meaning of the cognitive category "homosexual" before he/she can place him/herself in the category, and he stresses the role of knowledge in the process of coming out by stating, "The change of self-identity in homosexual is intimately related to the access of knowledge and information concerning homosexuals and homosexuality" (p.193). The participants' need for the acquisition of 
broad knowledge during coming out was related to the formation of their "queer" identity for "integration and meaning-making between different, often contradictory sets of knowledges” (Egan, 2004, p. 125). This understanding rejected "dichotomous (or linear) notions of how power is exerted in society" and allowed "for a complex analysis of how transgressive, often covert paths of resistance are formed by those excluded from mainstream privilege and authority" (p. 125). Participants shared coming out experiences that reflected and acquired these "subjugated knowledges" (Foucault, 1980, p. 81). It involved a broader and more holistic understanding for participants to support ambiguity and contradictions that the word "information" did not represent. This paper recognizes the limited nature of "information" in its reference to a narrow domain in specific contexts.

I did not look for any help with coming out; I just dealt with it on my own. The main thing was my own realization with it. I think only because if I am okay with it that is all that matters. So I don't think that I would seek any information. No, no, not even at this point .... My biggest thing is that I have to be okay with me and once I am okay with me, then it doesn't really matter what people think. Ultimately, I have to live my life for me . . . . But I never talked to anyone about that. And I never thought about seeking information, or reading, or doing any kind of research about it.

The paper also recognizes the concept of knowledge that several participants (such as the one quoted above) spoke about in its broader meaning. This understanding of knowledge is reflected in its root verb "to know" in terms of meanings that individuals, groups of people, society, and communities, consciously or unconsciously, become aware of in order to internalize, negotiate, and reject (or accept) socially constructed perceptions, values, and behaviors. The phrase information support services is used in this paper to represent these meanings, mechanisms, and avenues that symbolize a broader sense of understanding and reality in the coming out process.

This is not to say that participants did not have the need for specific, targeted information. "Queer” youth face a unique disadvantage during the coming out process that is two-fold: 1) unlike racial minorities who have parents who teach coping skills for dealing with discrimination and intolerance, "queer” youth cannot rely on parents for such information (Lewis, 1984); 2) “queer” individuals may be the only minority whose own families consistently reject them (MacDonald, 1983). Several participants spoke about how perceiving the existence of positive resources (and finding them) (Waldner \& Magruder, 1999) and specific information that showed increased cultural acceptance, visibility, and “queer” affirming stories (D’Augelli, 1994) would have greatly facilitated disclosure of their “queer” identity to family members. After disclosure, many family members felt shock, disappointment, shame, isolation, or grief (LaSala, 2000). One participant said,

I also sought out books and printed material for my parents who both barely graduated high school. What I found printed about sexuality and so forth was full of jargon and on a much higher level ... . Libraries can provide materials for 
different levels of reading and be an open-minded source for whoever comes in and be able to offer information in a non-judgmental sort of way ... so had I known the library had a certain section or could have helped, I would have gone there and felt more comfortable .... And I think if there were more community programs and gay events that they tell you to go to at the library.

Participants felt that accurate information sources about "queer" issues during coming out times would have been important to share with close family and friends since the more these people found out about "queer" issues, the better their adjustment would have been to the participants' coming out process (Ben-Ari, 1995). It is important to recognize that family and friends of "queer" participants needed to be "re-educated" due to the "pervasive influence of outdated and biased information" (LaSala, 2000, p. 74). Education about "queer" issues and exposure to "queer" people were two mechanisms that participants suggested could ease the coming out process both for "queer" youth and those to whom they disclosed their identity. There was an intense need that participants felt for accurate and relevant information since they often reported "feeling different" (Herdt, 1989; Minton \& MacDonald, 1984) and alienated (Martin, 1982; Maylon, 1982) during the coming out process due to the lack of access to "identity-affirming resources" (Greene, 1994). Since "queer" youth have few social and political advocates, very few places that provide relevant information accessible to them, or they have little knowledge about apt resources where they can obtain "queer" information support services, agencies such as libraries, universities, high schools, health clinics, and community organizations must play a more proactive role in providing positive outlets for "queer" youth and in aggressively advertising their "queer” services.

Throughout the coming out process and particularly during the initial phases, participants recognized the role of the marginalizing heterosexist social and cultural environment as the most instrumental factor that shaped their coming out experiences. As one participant said,

I think I went through all the processing all the negativity that you hear about gays and lesbians and where did I fit in with that stereotype. I am not really butch and I am not really femme, so I had a hard time with identifying. I felt like I had to pick one because that's what I thought was expected of me, you know. Either I was butch or I was femme, and I didn't fit any role, so I found that very difficult .... At the health center I did notice that there was a lot of information about safe sex and sexuality issues and STDs but all in a heterosexual way as if no one else was supposed to exist. So maybe they could devote a small amount of space for information for safe sex for others.

Several participants revealed that such social and cultural assumptions and norms that were based on heterosexual expectations and stereotypes dictated their coming out behavior and created much fear, anxiety, and stress in the self and in the social acknowledgement of being "queer" to others (Sedgwick, 1990). As one participant stated, 
From 8 to 19 I didn't deal with coming out, though I knew and I hid it. I didn't say a word because I lived in such a small community and I just always knew it was wrong somehow. The religious part was so bred into me and so dictated to me that I knew, “Oh, goodness, don't say anything different.” That is the world I grew up in, a small town that you could fit in the library, that's how small it is. And they are backwards and illiterates in a lot of ways. If the preacher says it, then it's the gospel, end of the discussion type of place ... and when my family found out, my mom, she called and cussed my answering machine out, and then she called and cussed me out .... This woman from my church called my mom and said, "Do you know your son is a homosexual and he is going to die and go to hell?” And that just freaked my mom out, so she got mad and instead of taking it out on the person who told, she decided to call me and take it out on me.

This was also particularly reflected in schooling experiences of participants where the following practices were noted: 1) "brainwashing" of heterosexual roles and life goals (Herdt \& Boxer, 1993); 2) heterosexual socialization practices ingrained in children through adult and peer interactions and formal and informal curriculum (Sears, 1987); 3) building negative stereotypes of homosexual people (Savin-Williams, 1990); 4) condoning or at least tolerating by school authorities of verbal harassment and physical abuse of homosexuals (Abinati, 1994); 5) hatred and fear of homosexuals as a central theme in campus humor (Uribe \& Harbeck, 1992). Participants identified the potential role of libraries to address heterosexist and homophobic policies in American schools and called for stronger library-school partnerships to organize self-assessment fairs and information-sharing workshops on sexuality education in order to tackle ignorance and develop greater acceptance for “queer” students.

Participants reported a lack of understanding about “queer”-related socialization norms and availability of local information resources and people as significant concerns during times of disclosure to strangers about being "queer.” Libraries can play an important role in alleviating both these challenges faced by "queer" youth by providing a safe space to address "queer"-related topics and issues as well as acting as a place for community information and referral on "queer” resources. As one participant noted,

Coming out would have been easier to have had some groups available to me to go and physically meet with people. And it would have been so good to have the library provide safe meeting areas where I could go and express my questions and get some positive feedback . . . they should be an open-minded source on local gay information for whoever comes in and be able to offer information in a nonjudgmental sort of way. Maybe they should take a more aggressive role, to push community leaders, and even federal leaders to address unfair rules.

Libraries can proactively make a difference during times when "queer” youth come out to family/friends by expanding their collections to include materials that may be useful to individuals unaware of the coming out process and by hosting events for heterosexuals regarding dimensions associated with "queer" coming out experiences. Libraries can also be especially potent as awareness generators of coming out owing to 
their credibility as a respected information provider and to their popularity as a social and informational place. One participant stated,

I sought information that my parents could use to understand what I was going through, what it meant to be a lesbian. With them and with my brother it was more difficult because they are still completely ignorant and completely homophobic. So if the library had information or websites, would help to explain to them what it was. That it isn't a disease, that it cannot be changed, that it isn't a choice .... It would be great to have any type of information, especially if you have really strong religious parents, to kind of prepare some arguments that you know are gonna come.

Participants believed that libraries can be important supporters for "queer” youth to establish positive self-identification and to help in the integration with and acceptance of the "queer" community and individuals within the larger social fabric. For example, one participant observed,

Libraries with their reputation for their welcoming spirit, for protecting civil rights, for being state institutions they should be welcoming safe havens ... and also fight against inequalities like how homosexuals need to be treated equally to a heterosexual couple, so that one could carry the other on one's insurance, so that bereavement leave would be extended. The benefits that a heterosexual couple would get should be extended to a gay couple or a lesbian couple.

\section{Conclusion: A “Queer” Manifesto of Library Interventions}

Over the years, both public and academic libraries have made few advances in achieving equal representation of "queer" issues in their services, collections, and policies (Hawkins, 1994). Greenblatt \& Gough (1994) identified misinformation and prejudice, lack of availability of "queer" materials, censorship, and bibliographic access (for patrons who do not wish to talk to library staff) as major barriers to library service for "queer" patrons. "Although many public and academic libraries are engaged in developing their collections, compiling pathfinders and guides, and offering other types of services, LBGTQ users are still vastly underserved and library collections vastly underdeveloped” (Greenblatt, 2001). Library recognition of the need to become more user-friendly to “queer” patrons, sensitive collection management that permits obtaining and maintaining adequate materials of specific interest to "queer" patrons, and the need to make people aware of "queer" collections are some noteworthy directions for library efforts (Gough, 1990; Seidel, 1998). It is quite debatable, however, what concrete efforts have been made in those areas. A recent library literature review recognizes that the homophobia of some librarians, the fear of a homophobic reaction from unknown librarians, the absence of appropriate materials, the lack of display or promotion of such items, and the lack of appropriate and relevant subject headings are some blocks to the provision of adequate information and services to the "queer” community (Joyce, 2000; Bott, 2000). 
A point to consider is that the library as an advocate for "queer" support is not uniformly practiced all over in the country in the same way (Taraba, 1990). Beyond anecdotal accounts, there is an urgent need to evaluate "queer" resources in libraries, study the advances and limitations in library information support services around the country, and provide more systematic documentation of services that libraries do provide to "queer" patrons. Also, the provision of adequate and appropriate information support services for "queer" youth is one area highly conspicuous by its absence in the priorities of libraries (Carter, 2005). And this in the light of the public library as the one place where most "queer" youth first find relevant information about who they are! (Kester, 1997). The reasons for lack of library attention to the needs of the "queer" youth population are many and include political pressures and fear of wrath from conservative patrons, the "ostrich phenomenon" in librarianship of burying one's head in the sand to avoid addressing controversial issues in a manner that really impacts people's lives, lack of leadership to address "queer" youth agenda, and others. This is true in spite of all the hoopla one sees and hears surrounding media-grabbing slogans showing libraries as providers of children’s information services (Walter, 2003).

To provide some direction in the future, the following is a brief "queer" manifesto that summarizes participants' responses regarding library interventions and significant areas where libraries need to provide greater proactive support to "queer" youth and adults in their coming out process. The "queer" manifesto for libraries includes initiatives that reflect (and require) extending the traditional library functions of information provision as well as fulfilling non-traditional expectations that include proactive social justice efforts for libraries to come out of the closet in support of "queer” youth.

Intervention 1: Provide greater access to "queer" materials based on the need for discreet information provision while at the same time calling for advertising strategies that promote awareness and visibility of "queer" collections, events, and local information support services. As a participant reported,

You also get into questions of access and costs of access. Was there information available where I was at the time? Probably, though I didn't know it, so that says much about the advertising for that information was poor. And if it was there, could I afford to access it? No. Meaning, there probably were websites, or reference books, or people that I could have talked to get the information I needed, but the costs would have been too high. Not just money. It would have been too embarrassing or too dangerous to ask those questions, to talk to those people, or ask for books.

Intervention 2: Develop the library as a thorough and encompassing community information system that not only provides access to "queer" information support services but acts as a referral to other more fitting "queer" avenues such as local support groups and counseling agencies.

Someone may be searching for more information on ways to meet people, both socially and romantically. Information on legal matters ... rights and what we need 
to do to procure and protect those rights. Libraries must know all the gay community activities and events, what is going on in the different areas in the locality, what are the community resources and supportive places, and also open up the world and make everything visible for all to know, not just for the gay students or community members, but for everyone's sake to try and make the city recognize that we exist and develop more resources for us.

Intervention 3: Expand use of the library's physical space to conduct “queer” workshops and sex education/health information classes, programs, events, and lecture series that draw attention to "queer” issues and counteract misperceptions and stereotypes.

I was gay and very deeply closeted at the time and just the thought of someone even knowing that I was gay just petrified me. If there had been a safe place to discuss what it all was and that it was ok .... Libraries are the places to coordinate different diversity awareness programs on gay material-films, speakers, book signings, bring special authors in. Have programs and information for everyone that might spawn conversation that might spawn more thoughts that are more positive, accepting thoughts.

Intervention 4: Reach out to local neighborhood groups, informal networks, middle and high schools, and institutions of faith to collaborate and effectively address hate crimes (or abuse) and create awareness and acceptance based on basic principles of equality, mutual understanding, and humanity.

I haven't gotten the statistics for this year, but last year, there were four deaths of gays in the surrounding communities. I can't help but think that if there were education, awareness, and resources, those deaths could have been prevented.

Intervention 5: Build information support services on local, regional, national, and international levels regarding "queer" history, culture, products of history and culture, narratives and stories, and personalities and have regular exhibits and programs to present to the community. One participant observed,

Libraries can make "queer” issues so much more visible and create openness and less fear to discuss the topic via say, they could do a GLBT theme month, have speakers brought in, get some themes going, put up some posters and flyers, or even a film during that month because that would encourage and show off the resources. It would say, "Hey, this is a minority that needs some attention and we do have the services available."

Intervention 6: Develop information and communication technologies for the application of "queer" information support services such as hosting "queer” mailing lists and newsgroups and developing and maintaining a local “queer” homepage about events, activities, and available resources. 
I have always sought out books and articles, preferably on the Internet, and I go into chat rooms online too. I wish there was information during coming out, to have, say, a librarian perhaps, that that was their subject focus, someone that maybe one could feel comfortable with. And then have digital reference where you chat with a librarian about sexuality or even have anonymous services on their web pages so that you could go to their web pages to get specific pieces of information anonymously. A page on coming out, gay resources in town, or places to hangout on the library web site would be so cool!

Intervention 7: Provide avenues for "queer” individual, social, cultural, political empowerment and community building via use of the media in all its different forms.

I think libraries need to advertise and let people know that they have stuff about homosexuality. Maybe some outreach to the gay and lesbian community that they are available. And then have a talk show on the radio where they talk about sexuality will be so helpful for my parents who have no exposure to gay culture and gay people, or just to say the word "gay." Maybe interviews with other parents of gay children on the TV and librarians talking to them, or school teachers doing a show on gay topics with children at the library.

Intervention 8: Partner with educational institutions, community organizations, public or private agencies, and others to remove legal, political, or social discrimination and prejudice (for example, help institutions develop “queer” inclusiveness in their nondiscrimination policies) via marketing, education, and community action. The following participant sums it up as follows:

Librarians have to take a much more proactive role, to push the seal on the envelope and force community leaders and even federal leaders “don't be silent anymore.” My initial reaction, even when I was out, was you don't make a big deal out of it. You don't rock the boat. Well, now I think we do need to rock the boat and wake up Americans from their false illusion that it is equal and fair for everyone because it is not and let us not pretend anymore.

The main goal of libraries should be not only to make libraries safe spaces for "queer" youth but also to initiate concrete actions that generate recognition and awareness among all the patrons (including “queer” youth) of the libraries as safe spaces of support for “queer” issues. Perception, visibility, and awareness are as important as what the reality may be. Projecting an image of “queer” acceptance and advocacy among all library users (or potential users) and identifying itself as a safe zone of support for sexuality-related issues is important even if it means going against conservative groups of library patrons (such as concerned parents who may fear their children will get "brainwashed" via exposure to "queer" materials). This is important because the primary function of libraries as a community resource is to provide access to a wide range of materials that diverse user populations may not be able to obtain elsewhere. Succumbing to the pressures of political and powerful constituencies (such as adults who have a "greater" voice than "queer" youth) goes against the strains of democracy and the 
American Library Association’s “Library Bill of Rights” that reflects the "professional obligation of librarians everywhere to provide the reading public a balanced collection of information on the full range of human concerns and public issues, and containing representative samples of all forms of personal and cultural expression (Gough, 1990, p. 3). Providing "queer" youth information support services and opportunities for health and well-being and destroying prejudice and intolerance in society against "queer" individuals are staunch expressions of this vision.

\section{Acknowledgements}

The authors would like to thank the participants who shared their coming out experiences reported in this research. We appreciate the financial support for gift vouchers that was provided by the School of Information Sciences at the University of Tennessee at Knoxville.

\section{List of References}

Abinati, A. (1994). Legal challenges facing gay and lesbian youth. In T. DeCrescenzo (Ed.), Helping gay and lesbian youth: New policies, new programs, new practice. New York: Harrington Park.

AIDS Education and Research Trust (AVERT). (2003). Talking about homosexuality in the secondary school ( $2^{\text {nd }}$ ed.). Sussex, UK: AVERT. Retrieved July 15, 2005, from http://www.avert.org/media/pdfs/homosexualityinschool.pdf

Anderson, K. (1993). Sources of coming out self-efficacy for lesbians. Unpublished doctoral dissertation, Michigan State University, Lansing.

Argus and Cox. (1999). Queer in the $21^{\text {st }}$ century: Perspectives on assimilation and integration. Brisbane, Australia: The Gay and Lesbian Welfare Association Inc.

Atkinson, J. D., III, \& Figueroa, M. (1997). Information seeking behavior of business students: A research study. The Reference Librarian, 58, 59-73.

Beaty, L. A. (1999). Identity development of homosexual youth and parental and familial influences on the coming out process. Adolescence, 34(135), 597-601.

Beheshti, J. (1989). Cross-sectional study of the use of library books by undergraduate students. Information Processing \& Management, 25(6), 727-735.

Ben-Ari, A. (1995). The discovery that an offspring is gay: Parents', gay men's and lesbians' perspectives. Journal of Homosexuality, 30, 89-112. 
Bilal, D. (2002). Children's use of the Yahooligans! Web search engine: III. Cognitive and physical behaviors on fully self-generated tasks. Journal of the American Society for Information Science \& Technology, 53(13), 1170-1183.

Bishop, K., \& Bauer, P. (2002). Attracting young adults to public libraries: Frances Henne/YALSA/VOYA Research Grant results. Journal of Youth Services in Libraries, 15(2), 36-44.

Blasius, M. (Ed.). (2001). Sexual identities, queer politics. NJ: Princeton University.

Blumenfeld, Warren J. (Ed.). (1992). Homophobia: How we all pay the price. Boston: Beacon.

Borgman, C. L., Hirsh, S. G., Walter, V. A., \& Gallagher, A. L. (1995). Children's searching behavior on browsing and keyword online catalogs: The science library catalog project. Journal of the American Society for Information Science (JASIS), 46(9), 663-684.

Bott, C. J. (2000). Fighting the silence: How to support your gay and straight students. Voice Youth Advocates, 23(1), 22-26.

Cain, R. (1991). Relational contexts and information management among gay men. Families in Society: The Journal of Contemporary Human Services, 72, 344-352.

Carter, J. (2005). United States: Reaching out with library services for GLBTQ teens. Buffalo, NY: Hawthorn.

Cass, V. C. (1979). Homosexual identity development: A theoretical model. Journal of Homosexuality, 4(3), 219-235.

Cass, V. C. (1984). Homosexual identity formation: Testing a theoretical model. Journal of Sex Research, 20(2), 143-167.

Chelton, M. K., \& Cool, C. (2004). Youth information seeking behavior: Theories, models, and issues. New York: Scarecrow.

Cianciotto, J., \& Cahill, S. (2003). Education policy: Issues affecting lesbian, gay, bisexual, and transgender youth. New York: The National Gay and Lesbian Task Force Policy Institute.

Coleman, E. (1982a). Developmental stages of the coming out process. In Paul, W., Weinrich, J. D., Gonsioreck, J.C., \& Hotvedt, M. E. (Eds.), Homosexuality: Social, psychological and biological issues (pp. 149-158). Beverly Hills, Ca: Sage.

Coleman, E. (1982b). Developmental stages of the coming out process. Journal of Homosexuality, 7(2-3), 31-43. 
Connexions. (2002/2003). Information and guidance on engaging young lesbian, gay and bisexual people. Nottingham, UK: DfES. Retrieved July 15, 2005, from http://www.connexions.gov.uk/partnerships/publications/uploads/cp/ LGBreprintfinal03.04.pdf

Crowley, P. (2004). Homosexuality and the counsel of the cross. Theological Studies, 65(3), 500-529.

D’Augelli, A. R. (1994). Lesbian and gay male development: Steps toward an analysis of lesbians' and gay men’s lives. In Greene, B., \& Herek, G. M. (Eds.), Psychological perspectives on lesbian and gay issues: Lesbian and gay psychology: Theory, research, and clinical applications (Vol. 1, pp. 118-132). Thousand Oaks, CA: SAGE.

Danesi, M. (2003). My son is an alien: A cultural portrait of today's youth. Lantham: Rowman \& Littlefield.

Dank, B. M. (1971). Coming out in the gay world. Psychiatry, 34, 180-197.

Dorais, M., \& Lajeunesse, S. L. (2003). Dead boys can't dance: Sexual orientation, masculinity, and suicide (P. Tremblay, Trans.). Montreal, Canada: McGillQueen's University Press.

Dresang, E. T., Gross, M., \& Holt, L. E. (2003). Project CATE: Using outcome measures to assess school-age children's use of technology in urban public libraries: A collaborative research process. Library \& Information Science Research, 25, 1943.

Egan, J. P. (2004). Not str8: The construction of queer male identity in Sydney, Australia. In Clover, D. E., Shinaba, J., \& Etmanski, C. (Eds.), Adult education for democracy, social justice and a culture of peace: Proceedings of the Joint International Conference of the Adult Education Research Conference (AERC) (45 ${ }^{\text {th }}$ National Conference) and the Canadian Association for the Study of Adult Education (CASAE), l'Association Canadienne pour l'etude de Feducation des Adultes (ACEEA) (23 ${ }^{\text {rd }}$ National Conference) (pp. 125-130). Victoria, Canada: National Library of Canada Cataloging in Publication.

Farmer, L. (2003). Electronic reference service. Knowledge Quest, 32(1), 22-23.

Fassinger, R. R., \& Miller, B. A. (1996). Validation of an inclusive model of sexual minority identity formation on a sample of gay men. Journal of Homosexuality, 32(2), 53-78.

Fikar, C. R., \& Koslap-Petraco, M. (1991). Pediatric forum: What about gay teenagers? American Journal of Diseases of Children, 145(3), 252. 
Flint, C. (2004). Space of hate: Geographies of discrimination and intolerance in the U.S.A. New York: Routledge.

Foucault, M. (1980). The history of sexuality (Vol. 1). New York: Vintage.

George, K. D., \& Behrendt, A. E. (1987). Therapy for male couples experiencing relationship problems and sexual problems. Journal of Homosexuality, 17, 77-88.

Glaser, B. G., \& Strauss, A. L. (1967). The discovery of grounded theory: Strategies for qualitative research. Chicago: Aldine.

Gough, C. (1990). Making the library more user-friendly for gay and lesbian patrons. In Gough, C. \& Greenblatt, E. (Eds.), Gay and lesbian library service (pp. 109-139). Jefferson, NC: McFarland.

Gough, C., \&. Greenblatt, E. (Eds.). (1990). Gay and lesbian library service. Jefferson, NC: McFarland.

Greenblatt, E., \& Gough, C. (1994). Gay and lesbian library users: Overcoming barriers to service. In Hill, K. H. (Ed.), Diversity and multiculturalism in libraries (pp. 227-233). New York: JAI.

Greenblatt, G. (2001). Barriers to GLBT library service in the electronic age. Information for Social Change, Number 12. Retrieved July 15, 2005, from http://www.libr.org/ISC/articles/12-Greenblatt.html

Greene, B. (1994). Lesbian and gay male development: Steps toward an analysis of lesbians' and gay men’s lives. In Greene. B., \& Herek, G. M. (Eds.), Psychological perspectives on lesbian and gay issues: Lesbian and gay psychology: Theory, research, and clinical applications (Vol. 1, pp. 118-132). Thousand Oaks, CA, US: SAGE.

Gross, L., \& Woods, J. D. (Eds.). (1999). The Columbia reader on lesbians and gay men in media, society, and politics. New York: Columbia University.

Hawkins, H. (1994). Opening the closet door: Public library services for gay, lesbian, \& bisexual teens. Colorado Libraries, 20(1), 28-31.

Herdt, G. (1989). Gay and lesbian youth. Journal of Homosexuality, 17(1-2), 1-42.

Herdt, G. (1992). Gay culture in America: Essays from the field. Boston: Beacon Press.

Herdt, G., \& Boxer, A. (1993). Children of horizons: How gay and lesbian teens are leading a new way out of the closet. Boston: Beacon. 
Herek, G. M., Jobe, J. B., \& Carney, R. M. (1996). Out in force: Sexual orientation and the military. Chicago, IL: University of Chicago.

Hooker, E. (1965). Male homosexuals and their world. In Marmor, J. (Ed.), Sexual inversion: The multiple roots of homosexuality (pp. 83-107). New York: Basic Books.

Howrey, M. M. (2000). A case study of library/community agency coordination and health information partnering practices: The Teen CARE Network (Illinois). Unpublished doctoral dissertation, Northern Illinois University, Dekalb.

Human Rights Campaign Foundation (HRCF). (2004). Resource guide to coming out for gay, lesbian, bisexual and transgender Americans. Washington, D.C.: HRCF. Retrieved July 15, 2005, from http://www.hrc.org/Template.cfm?Section=Resources2\&Template=/ContentMana gement/ContentDisplay.cfm\&ContentID=22631

Joyce, S. L. (2003). The discursive construction of lesbian, gay, and bisexual identity: How symbolic violence and information capital mediate the coming-out process. Unpublished doctoral dissertation, University of Western Ontario, London, ON.

Joyce, S. L. (2000). Lesbian, gay and bisexual library service: A review of the literature. Public Libraries, 39(5), 270-279.

Joyce, S. L., \& Schrader, A. (1997). Hidden perceptions: Edmonton gay males and the Edmonton Public Library. Canadian Journal of Information and Library Science 22, 19-37.

Julien, H. E. (1999). Barriers to adolescents' information seeking for career decision making. Journal of the American Society for Information Science, 50(1), 38-48.

Kafai, Y., \& Bates, M. J. (1997). Internet web-searching instruction in the elementary classroom: Building a foundation for information literacy. School Library Media Quarterly, 25, 103-111.

Kaufman, G., \& Raphael, L. (1996). Coming out of shame: Transforming gay and lesbian lives. New York: Random House.

Kester, N. G. (1997). Liberating minds: The stories and professional lives of gay, lesbian and bisexual librarians and their advocates. Jefferson, NC: McFarland.

Kirsch, M. H. (2001). Queer theory and social change. London, UK: Routledge.

Kubler-Ross, E. (1993). On death and dying. New York: Collier Books. 
LaBarbera, P. (1996). The gay youth suicide myth. Leadership U. Retrieved July 15, 2005, from http://www.leaderu.com/jhs/labarbera.html

LaSala, M. C. (2000). Lesbians, gay men, and their parents: Family therapy for the coming-out crisis. Family Process, 39(1), 67-81.

Laumann, E. O., Ellingson, S., Mahay, J., Paik, A., \& Youm, Y. (2004). The Sexual Organization of the City. Chicago, IL: University of Chicago.

Lee, J. A. (1977). Going public: A study in the sociology of homosexual liberation. Journal of Homosexuality, 3, 49-78.

Levin, D., \& Arafeh, S. (2002). The digital disconnect: The widening gap between Internet-savvy students and their schools. Pew Internet \& American Life Project Report. Retrieved May 9, 2004, from http://www.pewinternet.org/PPF/r/67/report_display.asp

MacDonald, G. B. (1983). Exploring sexual identity: Gay people and their families. Sex Education Coalition News, 5(1), 4.

Machado, J., Lentz, B, \& Wallace, R. (2000). A survey of best practices in youth services around the country: A view from one library. Journal of Youth Services in Libraries, 13(2), 30-35.

Martin, D. (1982). Learning to hide: The socialization of the gay adolescent. Adolescent Psychiatry, 10, 52-65.

Maylon, A. (1982). Biphasic aspects of homosexual identity information. Psychotherapy: Theory, research, and practice, 19, 335-340.

McDowell, S. (2000). Library instruction for lesbian, gay, bisexual, and transgendered college students. In. Jacobson, T. E, \& Williams, H. C. (Eds), Teaching the new library to today's users: Reaching international, minority, senior citizens, gay/lesbian, first generation, at-risk, graduate and returning students, and distance learners (pp. 71-86). New York: Neal-Schuman.

Mehra, B. (2005). A phase-model of the cross-cultural learning process of LIS international doctoral students: Characteristics and interventions. Proceedings of the American Society for Information Science \& Technology 2005 Annual Meeting: Sparking Synergies: Bringing Research and Practice Together @ ASIST '05.

Minton, H., \& McDonald, G. (1984). Homosexual identity formation as a developmental process. Journal of Homosexuality, 9, 91-104. 
Morris, J. F. (1997). Lesbian coming out as a multideimensional process. Journal of Homosexuality, 33(2), 1-22.

Pascoe, P. (2004). Why the ugly rhetoric against gay marriage is familiar to this historian of miscegenation. History News Network. Retrieved July 15, 2005, from $<$ http://hnn.us/articles/4708.html>

Perrin, E. C., Cohen, K. M., Gold, M., Ryan, C., Savin-Williams, R. C., \& Schorzman, C. M. (2004). Gay and lesbian issues in pediatric health care. Current Problems in Pediatric Adolescent Health Care, 34(10), 355-398.

Rankin, S. R. (1999). Queering campus: Understanding and transforming climate. Metropolitan Universities: An International Forum, 9(4), 29-38.

Rivers, I. (1997). Violence against lesbian and gay youth and its impact. In Schneider, M. S. (Ed.), Pride \& prejudice: Working with lesbian, gay and bisexual youth, Toronto, ON: Central Toronto Youth Services.

Russell, S. T. (2003). Sexual minority youth and suicide risk. American Behavioral Scientist, 46(9), 1241-1257.

Savin-Williams, R. (1990). Gay and lesbian youth: Expressions of identity. New York: Hemisphere.

Scasta, D. (1998). Issues in helping people come out. Journal of the Gay \& Lesbian Psychotherapy, 2(4), 87-98.

Schwandt, T.A. (1994). Constructivist, interpretivist approaches in qualitative research. In Denzin, N., \&. Lincoln, Y. (Eds.), The handbook of qualitative research (pp. 118-137). Thousand Oaks: SAGE.

Sears, J. (1987). Peering into the well of loneliness: The responsibilities of educators to gay and lesbian youth. In Molnar, E. (Ed.), Social issues and education: Challenge and responsibility. East Lansing, MI: National Center for Research on Teacher Learning.

Sedgwick, E. K. (1990). Epistemiology of the closet. Berkeley, CA: University of California.

Seidel, K. (1998). The "Invisibles": Lesbian women as library users. Progressive Librarian, No.14, 34-40.

Shenton, A. K., \& Dixon, P. (2002). Youngsters' use of and attitudes to their school libraries. The School Librarian, 50(4), 176-178. 
Spielberger, J., Horton, C., Michels, L., \& Halpren, R. (2004). New of the shelf: Teens in the library-Findings from the evaluation of public libraries as partners in youth development. Chicago, IL: Chapin Hall Center for Children, University of Chicago.

Stenback, T. L., \& Schrader. A. M. (1999). Venturing from the closet: A qualitative study of the information needs of lesbians. Public Library Quarterly, 17(3), 37-50.

Strauss, A., and Corbin, J. (1994). Grounded theory methodology. In Denzin, N., and Lincoln, Y. (Eds.), The handbook of qualitative research (pp. 273-285). Thousand Oaks: Sage Publications.

Swigonski, M. E., Mama, R. S., \& Ward, K. (2001). From hate crimes to human rights: A tribute to Matthew Shepard. New York: Haworth Press.

Taraba, S. (1990). Collecting gay and lesbian materials in an academic library. In Gough, C., \& and Greenblatt, E. (Eds.), Gay and lesbian library service (pp. 25-37). Jefferson, NC: McFarland.

Temes, R. (1980). Living with an empty chair: A guide through grief, ( $2^{\text {nd }}$ ed.). New York: Irvington.

Todd, R. J. (1999). Utilization of heroin information by adolescent girls in Australia: A cognitive analysis. Journal of the American Society for Information Science, 50(1), 10-23.

Troiden, R. R. (1979). Becoming homosexual: A model of homosexual identity acquisition. Psychiatry, 42, 363-373.

Uribe, V., \& Harbeck, K. M. (1992). Addressing the needs of lesbian, gay, and bisexual youth: The origins of Project 10 and school-based intervention. In. Harbeck, K. M. (Ed.), Coming out of the classroom closet: Gay and lesbian students, teachers and curricula. New York: Haworth.

Utter, G. H., \& True, T. L. (2004). Conservative Christians and political participation: A reference handbook. Santa Barbara, CA: ABC-CLIO.

Waldner, L. K., \& Magruder, B. (1999). Coming out to parents: Perceived resources and identity expression as predictors of identity disclosure for gay and lesbian adolescents. Journal of Homosexuality, 37(2)83-100.

Walter, V. A. (2003). Public library service to children and teens: A research agenda. Library Trends, 51(4), 571-589.

Westheimer, R.K. (1995). Sex for dummies. Foster City, CA: IDG Books. 
Whitman, J. S., Cormier, S., \& Boyd, C. J. (2000). Lesbian identity management at various stages of the coming out process: A qualitative study. International Journal of Sexuality and Gender Studies, 5(1), 3-18.

Willett, H. G. (1995). Public library youth services. Westwood, CT: Greenwood.

Winston, M., \& Paone, K. L. (2001). Reference and information services for young adults. Reference \& User Services Quarterly, 41(1), 45-51.

\section{Appendix}

Appendix 1: Interview Questions about the Role of Libraries during the Coming Out Process for “Queer” Individuals

1. [Introduction] Let us begin with general introductions. This is completely optional. Please tell us only what you are comfortable sharing about yourself and/or your "queer"-related experiences at the [name of university].

2. [Concerns during the coming out process] What does coming out mean to you? Think back to when you came out or perhaps a friend's experiences of coming out. Within a few years, can you state the year when you/your friend began the coming out process? What experiences did you go through during different times in the coming out process that were meaningful to you or your friend? What factors shaped coming out experiences for you or your friend?

3. [During the initial stages of coming out] What kinds of concerns did you have during these times? What types of information did you seek? What kinds of library and information support services did you find? What kinds of library and information support services would have helped during these times?

4. [When you first started coming out to other "queers"/starting friendships with other "queers"] What kinds of concerns did you have during these times? What types of information did you seek? What kinds of library and information support services did you find? What kinds of library and information support services would have helped during these times?

5. [When you were preparing to come out to close friends and family] What kinds of concerns did you have during these times? What types of information did you seek? What kinds of library and information support services did you find? What kinds of library and information support services would have helped during these times?

6. [After coming out] What kinds of concerns did you have during these times? What types of information did you seek? What kinds of library and information support services did you find? What kinds of library and information support services would have helped during these times? 
7. [Library and Information Services] How can the university/community improve its library and information services for "queer" individuals? [Prompts: development of library collections, access to library/information services; representation on campus website; and training of departments and dorms staff]

8. [Over-all] Is there anything else that libraries can do to make life for "queer" individuals better? What can the library at the university/community do to make life a more positive experience for "queer" individuals? 